\title{
COMPETITION AND REGULATION REFORMS IN SPAIN IN 2013: THE CNMC - AN INTERNATIONAL PERSPECTIVE
}

\author{
Ramon Xifré
}


The Public-Private Sector Research Center is a Research Center based at IESE Business School. Its mission is to develop research that analyzes the relationships between the private and public sectors primarily in the following areas: regulation and competition, innovation, regional economy and industrial politics and health economics.

Research results are disseminated through publications, conferences and colloquia. These activities are aimed to foster cooperation between the private sector and public administrations, as well as the exchange of ideas and initiatives.

The sponsors of the Public-Private Sector Research Center are the following:

- Ajuntament de Barcelona

- Departament d' Economia i Coneixement de la Generalitat de Catalunya

- Departament d' Empresa i Ocupació de la Generalitat de Catalunya

- Diputació de Barcelona

- Fundació AGBAR

- Institut Català de les Empreses Culturals (ICEC)

- PricewaterhouseCoopers

- Sanofi

- FGC

The contents of this publication reflect the conclusions and findings of the individual authors and not the opinions of the Center's sponsors. 


\title{
COMPETITION AND REGULATION REFORMS IN SPAIN IN 2013: THE CNMC - AN INTERNATIONAL PERSPECTIVE
}

\author{
Ramon Xifré
}

\section{Abstract}

This paper reviews, from an applied, policy-oriented point of view, the process of the creation of the new macro regulator in Spain, the CNMC, which concluded at the end of 2013. The institutional reform merged the competition authority with practically all sector regulators (except for the financial regulator). The aim is to ascertain in which respects the Spanish reform is approaching, or deviating, from international best practices in the matter. Although there is no universally superior model in terms of specific institutional arrangements, there is enough knowledge on similar episodes of institutional reform to state that, in the Spanish case, important shortcomings remain with the proposal that has finally been adopted. The paper also deals with a non-institutional dimension of the reform: the regulatory and competition competences that, in the midst of the CNMC process, the Spanish government has recovered for itself.

\footnotetext{
${ }^{1}$ Professor, ESCl - Universitat Pompeu Fabra
}

\footnotetext{
* The author thanks Xavier Vives, Lluís Torrens and Francesc Trillas for their helpful comments and acknowledges the financial support of FUNCAS. The usual disclaimer applies.
} 


\section{COMPETITION AND REGULATION REFORMS IN SPAIN IN 2013: THE CNMC - AN INTERNATIONAL PERSPECTIVE}

\section{Introduction}

Several European Union countries have been relatively active in recent times in reforming the institutional organization of the competition and regulatory authorities. This in some way reflects that competition and regulatory issues are gaining momentum in economic policy agendas.

One possible explanation for the surge in this particular type of structural reform is that governments may have realized that action on this front is one of the few remaining tools to free the growth potential of the economy. Fiscal stimulus in general needs to be very carefully administered and old-fashioned industrial policies involving direct subsidies are on the decline. Furthermore, and even before getting into crisis mode, in the particular case of the EU, the progress in competition policy has been consubstantial with the political and economic integration in the region (Cini and McGowan, 2009).

The purpose of this paper is to examine the competition and regulation institutional reforms adopted recently in Spain, more specifically the creation of the National Commission for Competition and Markets (CNMC) in 2013. As mentioned above and acknowledged by the Spanish government, a major rationale for undertaking this reform is the idea that it will be highly effective in overcoming the crisis and reigniting growth. For this very same reason, it is important to ascertain whether the broad direction and specifics of the Spanish reform are the appropriate ones and aligned with international best practices.

To reach this goal, the paper first reviews the most relevant international, EU and national experiences and recommendations in reforming the competition and regulatory institutions (Section 2). The main message that emerges from this section is that while it is very hard to come up with institutional arrangements that are globally optimal, there are several particular stylized facts that characterize the most successful reforms and that have earned the general approval of practitioners and academics.

After this, we focus on the particular reform that the Spanish government has implemented by creating the CNMC in 2013 (Section 3). We first briefly review the state of affairs in the competition and regulatory institutions before that year and then examine the CNMC reform process as well as the content itself. 
The final section (Section 4) concludes by comparing and contrasting the best practices documented in Section 2 with the actual reform discussed in Section 3. This section also provides some policy suggestions for improvement.

\section{The Framework for Reform}

\subsection{International Evidence for the Reform of Competition Authorities}

\section{International Evidence}

There is general agreement that any effective competition policy is characterized by a number of features, with the two main principles being independence and accountability (UNCTAD, 2008).

Independence from political interference and business influences is required in order to ensure that an agency's decisions are not politicized, discriminatory or implemented on the basis of the narrow goals of interest groups. At the same time, independent competition institutions are expected to be subject to government oversight and a well-defined system of checks and balances.

The principle of accountability requires that all relevant stakeholders affected by competition decisions (the business community, the consumers and the public administrations) must know who is responsible for a decision and the reasoning behind it. This principle also extends to the requisite that affected parties must be able to provide input through well-established, publicly known and open consultation processes.

The particular way in which these two general principles are applied in each country or economic region obviously differs, but still there are some international best practices that can be considered as robust guidelines for reform.

Following the UNCTAD (2011), several formal safeguards have been employed internationally to ensure the independence of the competition institutions:

a. Providing the competition authority with an explicit and distinct statutory authority that frees it from day-to-day ministerial control;

b. Prescribing well-defined and objective professional criteria for appointments;

c. Involving both the executive and the legislative branches of government in the appointment process;

d. Appointing the director-general and the Board members for a fixed period and prohibiting their removal, except for a clearly defined due cause;

e. Where a collegiate structure has been chosen for a Board or commission, staggering the terms of the members so that they can be replaced only gradually by successive governments;

f. Providing the agency with a reliable and adequate source of funding; optimally, charges for specific services can be used to fund the competition agency to insulate it from political interference via the budget process;

g. Exempting the competition agency from civil service salary limits in order to attract and retain the best qualified staff and ensure adequate good governance incentives; 
h. Prohibiting the executive from overturning the agency's decisions, except through carefully designed channels such as new legislation or appeals to the courts based on current law.

The UNCTAD has also documented specific arrangements that international competition authorities should adopt to warrant accountability:

a. Publishing the competition law and statutes of the competition agency; these regulations should very clearly specify the duties, responsibilities, rights and obligations of the institution;

b. Ensuring that the competition agency's decisions are subject to review by the courts or some other non-political entity;

c. Requiring the competition authority to publish annual reports on its activities, and requiring a formal review of its performance by independent auditors or oversight committees of the legislature;

d. Establishing rules for the removal of members of the Board if they show evidence of misconduct or incompetence;

e. Allowing all interested parties to make submissions to the competition agency on matters under review;

f. Mandating that the competition authority publish its reasoned decisions.

A growing number of competition authorities around the world are institutionally independent from ministerial control. According to more recent figures from the UNCTAD (2011), competition authorities have been established in 112 countries and more than half of these authorities are separate from the ministries.

Apart from the requisites on independence and accountability, competition agencies also need to have an adequate level of enforcement powers; in other words, they "must have sharp teeth." In particular, the competition agencies are expected to be able to investigate effectively so that they can gather information in a timely manner and they are in a position to impose sanctions for non-compliance. Along this line, the International Competition Network (ICN) stresses that the quality of a competition agency's enforcement depends on its ability to conduct effective investigations (International Competition Network, 2013). They recommend that competition authorities be granted legal authority to obtain all relevant information, through the appropriate investigative tools, and in turn that the necessary institutional mechanisms be put in place to ensure that available evidence is given adequate consideration.

The range of investigative tools that the ICN encourages competition agencies to adopt is wide, including inspections on business premises, compulsory interviews, and phone or wiretaps, in all cases respecting the national legal guarantees.

\section{The Experience in the EU}

The experience of the Directorate-General for Competition in the European Commission is evidently of particular interest when considering reforms of the competition systems in EU countries. 
The DG Competition has been undertaking far-reaching institutional reforms with the ultimate goal of delivering a modern and effective framework for competition policy in the EU. According to Lowe (in Vives, ed. 2009), some of the main institutional and operative reforms that the DG Competition has adopted are as follows:

a. The creation, starting in 2003, of a matrix structure by integrating merger units with antitrust units in directorates dedicated to enforcement action in key sectors of the EU economy such as energy, telecoms, transport, financial services, and information technology. The reform in 2007 went one step further: it also integrated state aid units and resulted in five "market and cases" directorates.

b. The creation of a chief competition economist function in 2003. The chief economist is expected to provide general guidance on the economic methodology in competition investigations and to deliver detailed orientations in key cases involving complex economic issues, in particular those requiring sophisticated quantitative analysis.

c. Setting priorities and allocation of resources on project-based terms. This is a way to somehow overcome the inevitable administrative rigidity that results from the organization of the directorate-general in directorates, which are in turn composed of units. This flexibility allows the staff of one unit to be moved temporarily to another one if required by additional workload.

\subsection{Recent Developments in the Reform of EU National Competition Authorities}

Turning now to national competition policy systems in the EU, their legal structure and functioning can be classified from two broad perspectives, following Cseres (2010):

- The scope of competences of national competition authorities (NCAs);

- Whether the competition policy system places the two main competition policy functions (investigation and decision making) in one single authority or in a dual system with two bodies or institutions.

In terms of competences assigned to the NCA, there are three main legal-institutional models across the EU. The first, more restrictive model implies that the sole responsibility of the NCA is the enforcement of the competition law (like in Belgium, Spain before 2013, and Romania). The second model entails that some sort of sector regulation (e.g., energy, telecommunications) is also part of the competencies assigned to the NCA (e.g., Denmark, Austria, and Spain after 2013). Finally, the third type of agencies are those that combine the enforcement of competition law with some specific parts of consumer law, such as rules against deceptive or misleading advertising (like in Italy, Poland, and the Netherlands after 2013).

Of particular interest are the recent institutional transitions in the Netherlands and in the United Kingdom. In the Netherlands, in April 2013 the new Authority for Consumers and Markets (ACM) was created as a result of the merger between the former Netherlands Competition Authority (NMa), the independent Post and Telecommunication Authority (OPTA), and the Consumer Authority. It includes the functions of regulation of the energy markets (see Figure 1). This degree of quasi absolute integration is new and somehow rare in EU countries and it is only comparable with that of the Estonian Competition Authority (see Figure 2). 
Figure 1

The organization of the Dutch Authority for Consumers and Markets, 2013

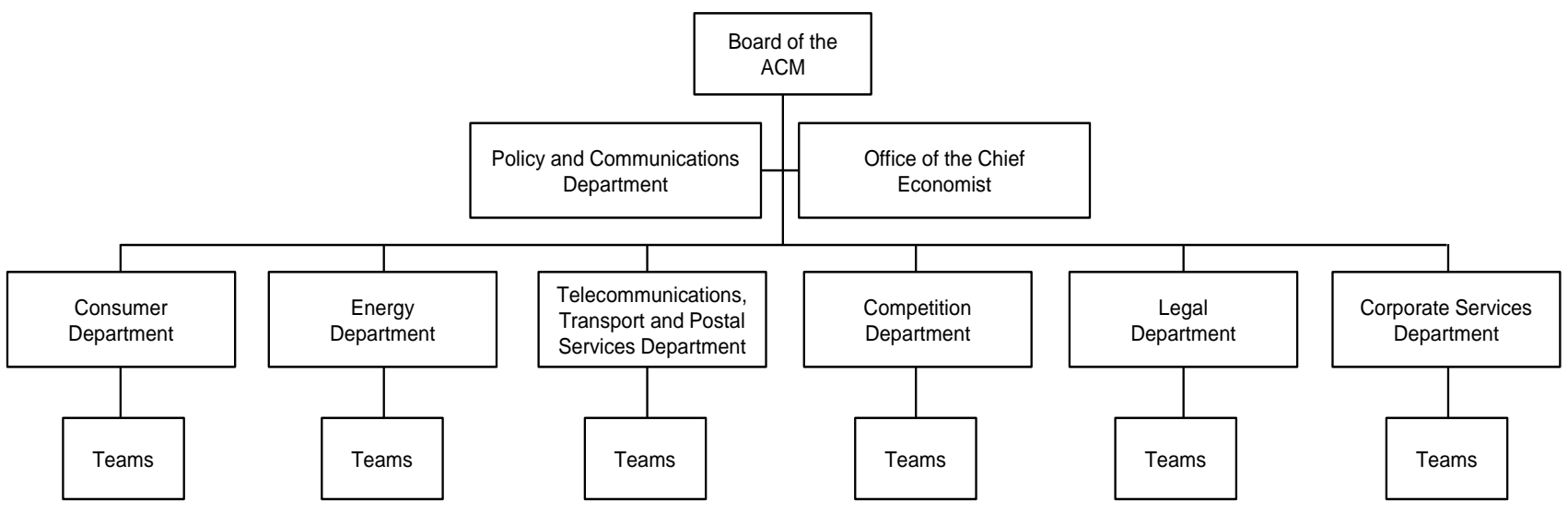

Source: Dutch Authority for Consumers and Markets.

Figure 2

The organization of the Estonian Competition Authority, 2013

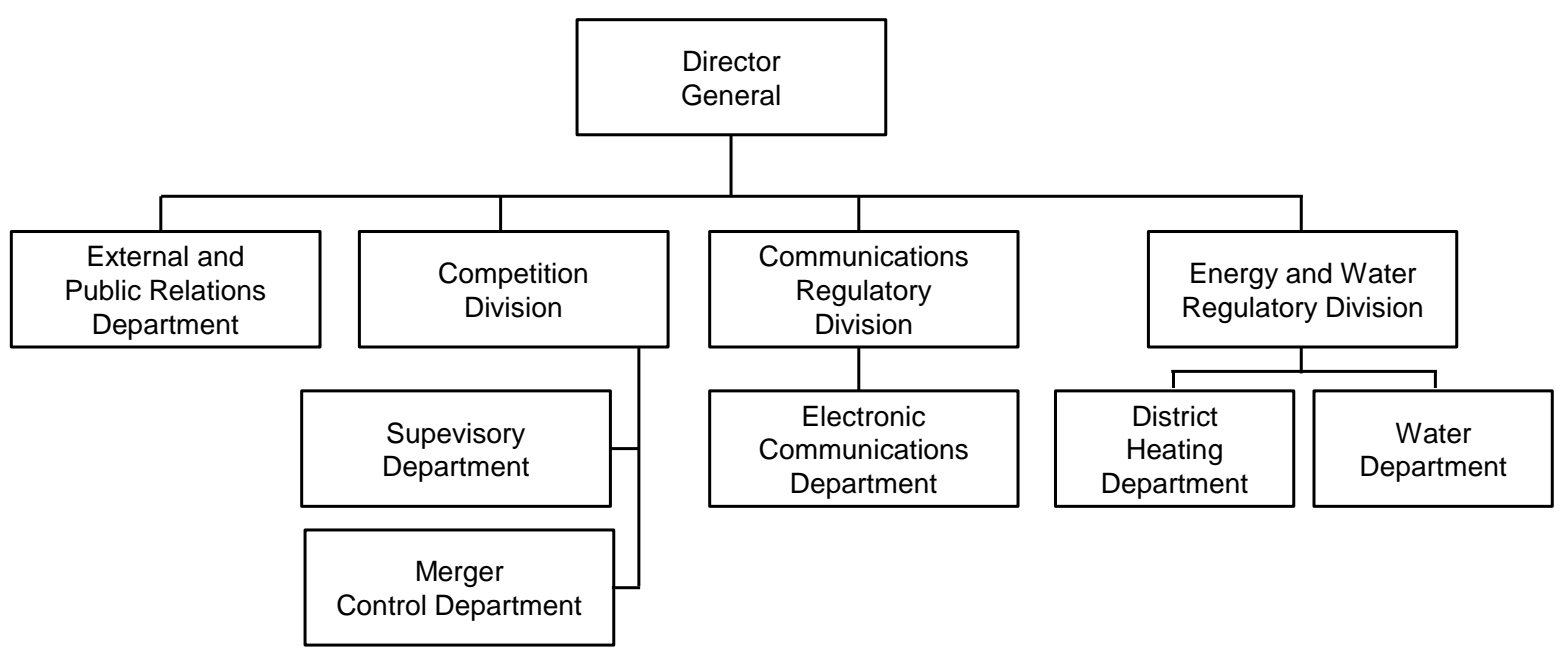

Source: Estonian Competition Authority. 
Also noteworthy is the case of the United Kingdom. The Competition and Markets Authority (CMA) was legally established on October 1, 2013, and it will become fully operational on April 1, 2014. The new body will merge the Competition Commission (CC) with the competition functions and certain consumer functions of the Office of Fair Trading (OFT). The consumer protection principle is of the essence for the new authority, whose primary duty is to "promote competition, both within and outside the United Kingdom, for the benefit of consumers"; and one of its five high-level goals is to "refocus consumer protection," i.e., to "empower consumers to exercise informed choice, using both competition and consumer powers to help markets work well” (CMA, 2014).

However, in contrast to the Netherlands, in the U.K. model the competition authority and regulatory bodies are separate entities, with the latter generally having exclusive competition policy rights in its respective regulated sectors. The most notable sector regulators are Ofcom (communications industries), Ofgem (electricity and gas markets), Ofwat (water services), the Office of Retail Regulation, the Civil Aviation Authority, the Office of the Rail Regulation and the Financial Conduct Authority.

This separation between regulation and competition bodies has been a long-standing institutional design feature of the U.K. competition policy framework. Indeed, the launching of the CMA is seen as an opportunity to create a new U.K. competition network by setting the CMA the goal of "working alongside and supporting" the abovementioned sector regulators (CMA, 2014).

In terms of the internal structure of the NCA, most member states have a system of a single administrative authority that both investigates and decides on the cases, although the units are internally independent. In the past years, some member states, like Spain (2007), France (20082009) and Estonia (2009), have migrated from dual to single systems. On the other hand, Belgium and Luxembourg currently still opt for a dual administrative system, while in Ireland and Austria the investigations are carried out by the respective competition authorities, with the decision-making powers having been transferred to the courts. 
Table 1 summarizes these two criteria for the classification of NCAs in the EU27 with their current structure, marking the recent changes in Spain, the Netherlands and the United Kingdom.

Table 1

Classification of national competition authorities in the EU

\begin{tabular}{|c|c|c|c|c|c|}
\hline & \multicolumn{3}{|c|}{$\begin{array}{l}\text { Scope } \\
\text { Functions attributed to the NCA }\end{array}$} & \multicolumn{2}{|c|}{$\begin{array}{l}\text { System } \\
\text { Are the investigation and decision- } \\
\text { making functions attributed to one } \\
\text { or to two institutions? }\end{array}$} \\
\hline & $\begin{array}{c}\text { Competition } \\
\text { only }\end{array}$ & $\begin{array}{l}\text { Competition } \\
+ \text { regulated } \\
\text { sectors }\end{array}$ & $\begin{array}{l}\text { Competition } \\
+ \text { consumer } \\
\text { protection }\end{array}$ & Two & One \\
\hline Austria & & $\mathrm{X}$ & & $\mathrm{X}$ & \\
\hline Belgium & $X$ & & & $X$ & \\
\hline Bulgaria & & $X$ & & & $X$ \\
\hline Cyprus & $X$ & & & & $X$ \\
\hline Czech Republic & & $\mathrm{X}$ & & & $X$ \\
\hline Denmark & & $X$ & & & $X$ \\
\hline Estonia & & $\mathrm{X}$ & $\mathrm{X}$ & & $\mathrm{X}$ \\
\hline Finland & $X$ & & & & $X$ \\
\hline France & & & $X$ & & $\mathrm{X}$ \\
\hline Germany & $\mathrm{X}$ & & & & $\mathrm{X}$ \\
\hline Greece & $\mathrm{X}$ & & & & $\mathrm{X}$ \\
\hline Hungary & & $X$ & $X$ & & $X$ \\
\hline Ireland & & & $X$ & $\mathrm{X}$ & \\
\hline Italy & & & $X$ & & $X$ \\
\hline Latvia & & $X$ & $\mathrm{X}$ & & $\mathrm{X}$ \\
\hline Lithuania & & & $X$ & & $X$ \\
\hline Luxembourg & $\mathrm{X}$ & & & $\mathrm{X}$ & \\
\hline Malta & & & $X$ & & $X$ \\
\hline Netherlands & * $\quad--$ & $\begin{array}{c}(\mathrm{ACM}, \text { after } \\
\text { 2013) }\end{array}$ & $\begin{array}{c}-\rightarrow X \\
(A C M, \text { after } \\
\text { 2013) }\end{array}$ & & $\mathrm{X}$ \\
\hline Poland & & $\mathrm{X}$ & & & $X$ \\
\hline Portugal & $X$ & & & & $\mathrm{X}$ \\
\hline Romania & $X$ & & & & $X$ \\
\hline Slovakia & $\mathrm{X}$ & & & & $\mathrm{X}$ \\
\hline Slovenia & $X$ & & & & $X$ \\
\hline Spain & $\begin{array}{l}{ }^{*}{ }^{*}--- \\
\text { (CNC, before } \\
\text { 2013) }\end{array}$ & $\begin{array}{c}-\rightarrow X \\
\text { (CNMC, after } \\
\text { 2013) }\end{array}$ & & & $x$ \\
\hline Sweden & & $\mathrm{X}$ & & & $X$ \\
\hline United Kingdom & * -- & --------- & $\begin{array}{c}-\rightarrow X \\
(\mathrm{CMA}, \text { after } \\
\text { 2014) }\end{array}$ & & $\mathrm{X}$ \\
\hline
\end{tabular}

Source: Author's preparation based on Cseres (2010). 


\section{Competition and Regulatory Reform in Spain}

\subsection{Overview of the Competition and Regulation Institutions in Spain Before 2013}

\section{The Competition Institutions}

Spain had real competition policy institutions only as a result of the process of integration into the European Economic Community (EEC), although the first competition law was formally passed in 1963 (see CNC, 2012a, for further references). The process of reform crystallized in a new competition law passed in 1989, which relied on two standing administrative bodies, the Service for the Defense of Competition (SDC) and the Court for the Defense of Competition (TDC), to implement the competition policy. The SDC was a directorate-general within the Ministry of Economy and Finance, initially performing information-gathering functions and later taking on competition promotion functions as well. The TDC was of a more juridical nature but equally dependent on the ministry. The limitations of this institutional arrangement became increasingly evident over time in the form of a lack of synergies, the duplication of procedures and weak transparency levels.

It is also noteworthy that the Spanish Constitutional Court acknowledged that the Spanish regions had legal competences that were not properly acknowledged in the 1989 law. This, in parallel with major developments in the EU competition policy arena arising from Regulation $1 / 2003$, paved the way for a sort of radical transformation of the competition institutional and legal frameworks in Spain.

On both fronts, both legal and institutional reform, an open process of consultation with stakeholders started in 2005. The process integrated inputs from many parties: the incumbent competition institutions, the political parties, the trade unions and the business community as well as the academics. The process reached an important milestone with the preparation of a white paper on the issue and it successfully reached its goal when the Spanish parliament passed the new competition law (Law 15/2007) with practical political unanimity.

The new law not only upgraded the legal framework but also created a new institution, the National Competition Commission (CNC). The CNC integrated the two previous competition institutions, the TDC and the SDC, and it operated in a hierarchical mode. A president was appointed by the government to coordinate the CNC and there were three major operative units: the Directorate-General for Investigation, whose function was mainly information gathering and the preparation of the dossiers; the Council, composed of six members, including the president, with the function of decision making over the dossiers; and the Directorate-General for Promotion, which was commissioned the task of analyzing the competition climate in Spain and preparing reports. Supporting these units, the CNC also had a general secretariat and an economic advisory section, which for a period of time held a chief economist function but later remained as a support unit to the DG of Promotion (see Figure 3). 


\section{Figure 3}

\section{The organization of the CNC in 2013}

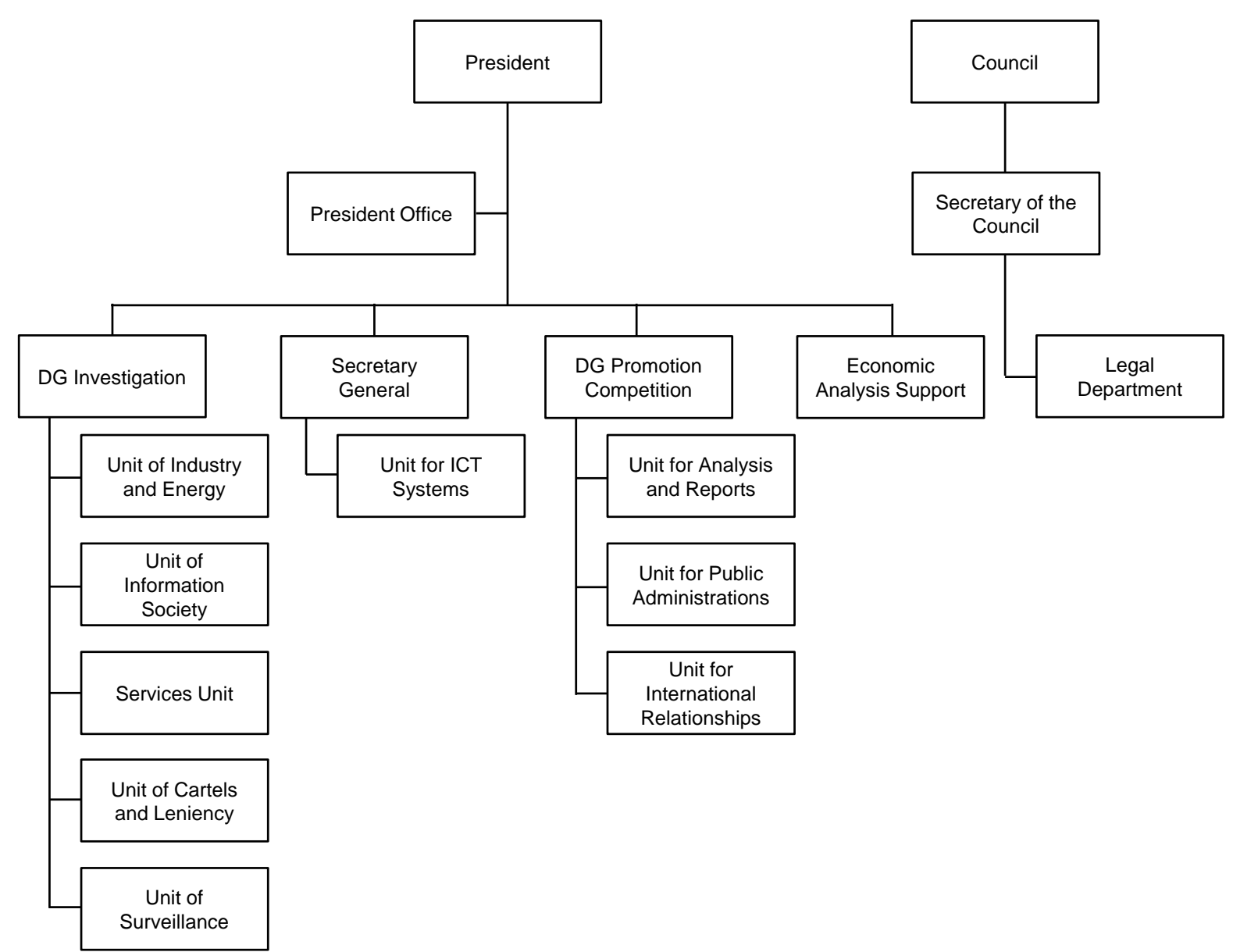

Source: CNC.

In 2010, the Spanish parliament passed an act (Law 2/2011) that introduced the requirement of a hearing for the president of the CNC, as well as for the presidents of the other regulatory bodies, in the Spanish parliament before confirming their appointment. This law also established that the councils of these institutions would be made up of seven members, including the president.

In terms of staffing, the CNC reached a maximum of 203 workers in 2009, though it later downsized to 181 employees in 2013. Regarding the composition of the staff, consistently more than $90 \%$ of workers have been civil servants at some point in time. And in terms of available resources, the CNC budget corresponding to 2013 was $€ 12.5$ million.

In relative terms to the five larger EU economies, the CNC budget per staff member, roughly $€ 68,500$, is the lowest one (see Table 2). With respect to the budget as a proportion of the GDP, the CNC is placed in the middle-low region with approximately $€ 12,200$ of budget per billion of GDP, much closer to the minimum figure corresponding to Germany $(€ 9,300)$ than to the maximum corresponding to the United Kingdom $(€ 54,200)$. 
Table 2

Staff and budget of the NCAs in the five larger EU economies, 2012/13

\begin{tabular}{lrrrrr}
\hline & Germany & France & U.K. & Italy & Spain \\
\hline NCA staff & 320 & 188 & 657 & 262 & 184 \\
NCA butget (million euros) & 25.0 & 20.4 & 104.6 & 53.0 & 12.6 \\
Country 2012 GDP (billion euros) & $2,666.4$ & $2,032.3$ & $1,929.6$ & $1,567.0$ & $1,029.0$ \\
NCA budget per billion of GDP, euros & $9,375.9$ & $10,037.9$ & $54,209.2$ & $33,822.4$ & $12,244.9$ \\
NCA budget per staff member, euros & $78,125.0$ & $108,510.6$ & $159,210.0$ & $202,290.1$ & $68,478.3$ \\
\hline
\end{tabular}

Source: NCA annual reports.

Of course, these comparisons need to be made with caution. One of the reasons is that while in those countries the competition authority is central, in Spain the legal attributions for promoting and investigating competition-related issues do not correspond exclusively to the CNC but also to the regional competition authorities. Indeed, there has been a gradual creation of regional competition authorities. By 2013, there were 10 such regional competition authorities corresponding to the regions of Andalusia, Aragon, the Basque Country, Castile and León, Catalonia, Extremadura, Galicia, the Canary Islands, Murcia and Valencia. The budget and staff of these regional competition authorities should be combined with that of the CNC to have a more complete comparison of the situation in the five larger EU countries.

Concerning the output of the competition enforcement activity by the CNC, the CNC has increased the financial penalties imposed on firms operating in Spain by a factor of eight during its seven-year period (see Figure 4).

\section{Figure 4}

Financial penalties imposed by the CNC for improper business behavior (million euros)

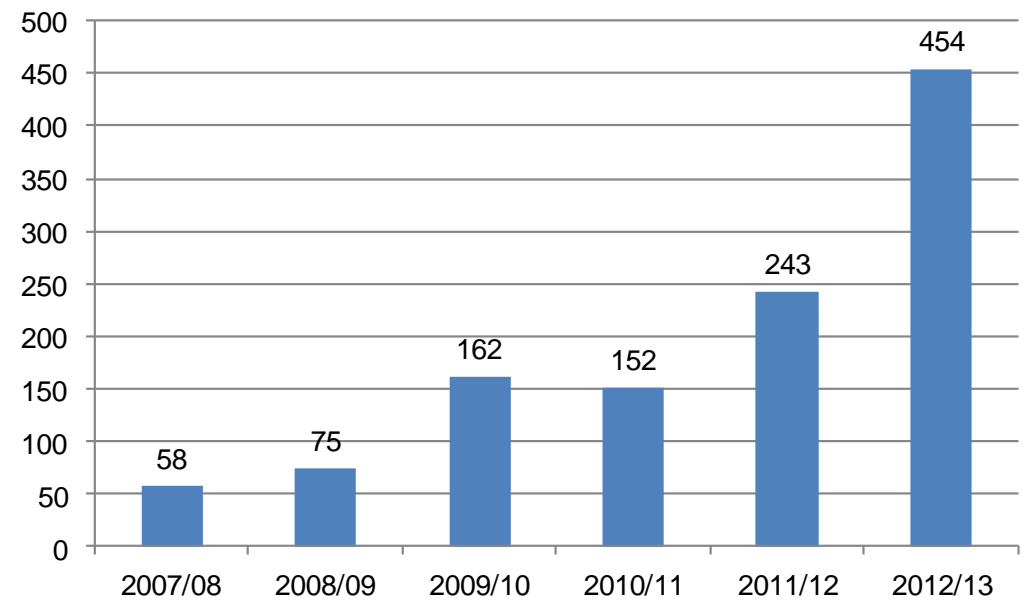

Source: CNC Report of Activities, 2012/13.

The CNC has stood as the main competition authority in Spain up until 2013 with an exclusive mandate on competition issues, including those in the regulated sectors. This has created some conflicts, as the CNC and the sector regulators have occasionally approached competition issues, mainly in energy and telecommunications, with different criteria. 
In October 2013, the new National Commission for Markets and Competition (CNMC) replaced the CNC and became fully operative by integrating the CNC functions together with the other regulatory functions.

\section{The Regulatory Institutions}

Until 2011 there were four regulatory authorities in Spain: the National Commission for Energy (CNE), the National Commission for Telecommunications (CNT), the Committee for Railway Regulation (CRF) and the National Commission for the Postal Service (CNSP).

The first two were large-caliber institutions, as can be appreciated from their budget and staff (see Table 3), with a proven record in regulatory policy and with a well-defined set of competences. Even in those two prominent cases, however, the Spanish government kept important legal competencies in the energy and telecommunication sectors for itself, like the ability to fix the pricing system in the electricity market.

Table 3

Budget and staff of the regulatory bodies in Spain, 2013

\begin{tabular}{lrc}
\hline Regulatory body & Staff & $\begin{array}{c}\text { Budget } \\
\text { (million euros) }\end{array}$ \\
\hline CNE (Energy) & 214 & 26.4 \\
CMT (Telecommunication) & 145 & 18.4 \\
CNSP (Postal Mail) & 23 & 1.8 \\
CRF (Railway) & 2 & 0.2 \\
Total & 384 & 46.8 \\
\hline
\end{tabular}

Source: Report on Legal Impact, CNMC Creation Act.

In addition to those well-known existing institutions, since 2010 there have been legal mandates to create three new regulatory authorities in the sectors of transportation, gambling and the audiovisual industry. These three projected organizations have not been created as stand-alone entities, and, instead, their functions have been implemented as administrative units within the new CNMC.

\subsection{The CNMC Reform}

\section{The Process of the Reform}

In January 2012, the Spanish government set up a ministerial taskforce with the mission of reforming the institutional framework of competition policy and regulatory architecture in Spain. The government was committed to implementing this reform in the second semester of 2012 as one of the economic policy measures included in the National Reform Program (NRP) submitted to the European Commission in 2012 (Government of Spain, 2012, pp. 225-226). This deadline was not met and the government included the reform commitment once again in the 2013 NRP (Government of Spain, 2013, pp. 73-76).

In contrast to the process that led to the creation of the CNC in 2007, the reform process that started in 2012 was strictly controlled by the ministries with very scarce external input. Indeed, when a draft law was ready by mid-May 2012, the European Commission released a report stating that "the current draft law that the CNMC creates does not guarantee that it will carry 
out its regulatory activity in an effective and independent way" (European Commission, 2012, p. 25). The Spanish government introduced changes in the law but the final approved version still included legal provisions that devolved regulatory powers to the ministries, as will be shown below.

In 2012, the CNC also released an assessment report (National Competition Commission, 2012b) on the draft of the reform. The report mentioned similar concerns to those expressed by the European Commission (risk of devolution of powers to the ministries), and, according to the CNC view, further additional issues raised were not satisfactorily addressed. The main ones were difficulties with the organizational architecture of the new institution (which posed a threat to some of the specialized expertise in regulatory and competition supervision) and the view that the financing of the CNMC was not sufficiently secure. The regulatory authorities in the energy and telecommunication sectors also released some fairly critical assessment reports on the reform (National Commission of Energy, 2012; Telecommunications Market Commission [CMT], 2012).

Finally, with a weaker political consensus than the 2007 reform, the law on the creation of the CNMC (Law 3/2013) was approved by parliament. It entered into force on June 4, 2013. The government had prepared a gradual implementation plan to ease the institutional transition. In August, Royal Decree 657/2013 was issued approving the statute of the functioning of the CNMC. In September, the 10 Council members were elected; on October 7 the CNMC was legally established as a full-standing public agency; and in November the director-generals were appointed.

\section{The Rationale for the Reform}

According to the Spanish government (in the preamble of Law 3/2013), the CNMC reform seeks to fulfill three main principles:

- respect for the rule of law and the value of institutional reliability;

- the ability to reap the benefits of economies of scale; and

- greater adaptation of the regulatory bodies to technological change.

Concerning the first principle, as put forward by the government, the main idea justifying the organizational change is that the overlapping of regulatory bodies with coincident legal responsibilities regarding the same economic activity or industry may damage desirable economic policy values such as predictability and the fulfilling of the rule of law. In an effort to alleviate this problem, integration shall bring coherence and clarity in the elaboration of regulation and competition enforcement. However, it should be noted that regulatory and competition functions are inherently different and, therefore, it may be desirable in some cases for the tension between these two approaches to be publicly discussed for the sake of greater consumer welfare.

In terms of the economies of scale derived from the integration, the government estimated that the creation of the CNMC would result in total savings of $€ 28$ million. However, two thirds of this figure is not a reduction in current spending but rather is imputed as the consequence of not establishing the regulatory bodies whose creation is mandated by law (in gambling, the audiovisual industry, and airports).

Finally, it is hard to see how the institutional reorganization of the CNMC makes the Spanish regulatory policy better able to cope with technological change. 


\section{The Content of the Reform}

A. Institutional Dimension

The CNMC has been created to perform two main functions:

- defense and promotion of competition in any market; and

- regulatory functions in the sectors and activities where competition and antitrust policy is not enough to ensure market efficiency.

The first function broadly corresponds with the functions of the former CNC while the second block represents the continuation of the tasks undertaken by the former regulatory agencies.

In terms of structure and governance, the CNMC governing bodies are the Council and the president. The Council, or Board, is a collegiate body with executive power and is made up of 10 members, including the president, whose function leans more towards representation and coordination. The members of the Council are appointed by the government, with the parliament having a veto right. They are appointed for a non-renewable term of six years and they are partially removed every two years in such a way that no Council member serves a term longer than six years.

The Council has two formations; it operates as a plenary and in two different sections or courts, each one in charge of one of the two main functions: competition and regulation. Council agreements are adopted by majority, with the president having a quality vote.

The subsequent legislation determining the functioning of the CNMC (Royal Decree 657/2013) leaves the organization of those sections or courts very open, allowing the plenary full autonomy to determine the specifics. The law imposes only mild restrictions: no Council member can be a permanent member of one section and the rotation of Council members between sections cannot be complete.

In operative terms, there are four directorates-general, each in charge of documenting and preparing the cases that will be submitted to the Council for deliberation and decision making. The four DGs are: Competition; Telecommunications and Audiovisual; Energy; and Transports and Postal Mail. In addition to these information-gathering DGs, there are two other directive units that provide general services (the Secretary General and the Department of Internal Control) and one Directorate-General for the Promotion of Competition, in charge of producing reports and analyses (see Figure 5). 


\section{Figure 5}

\section{The organization of the CNMC in 2013}

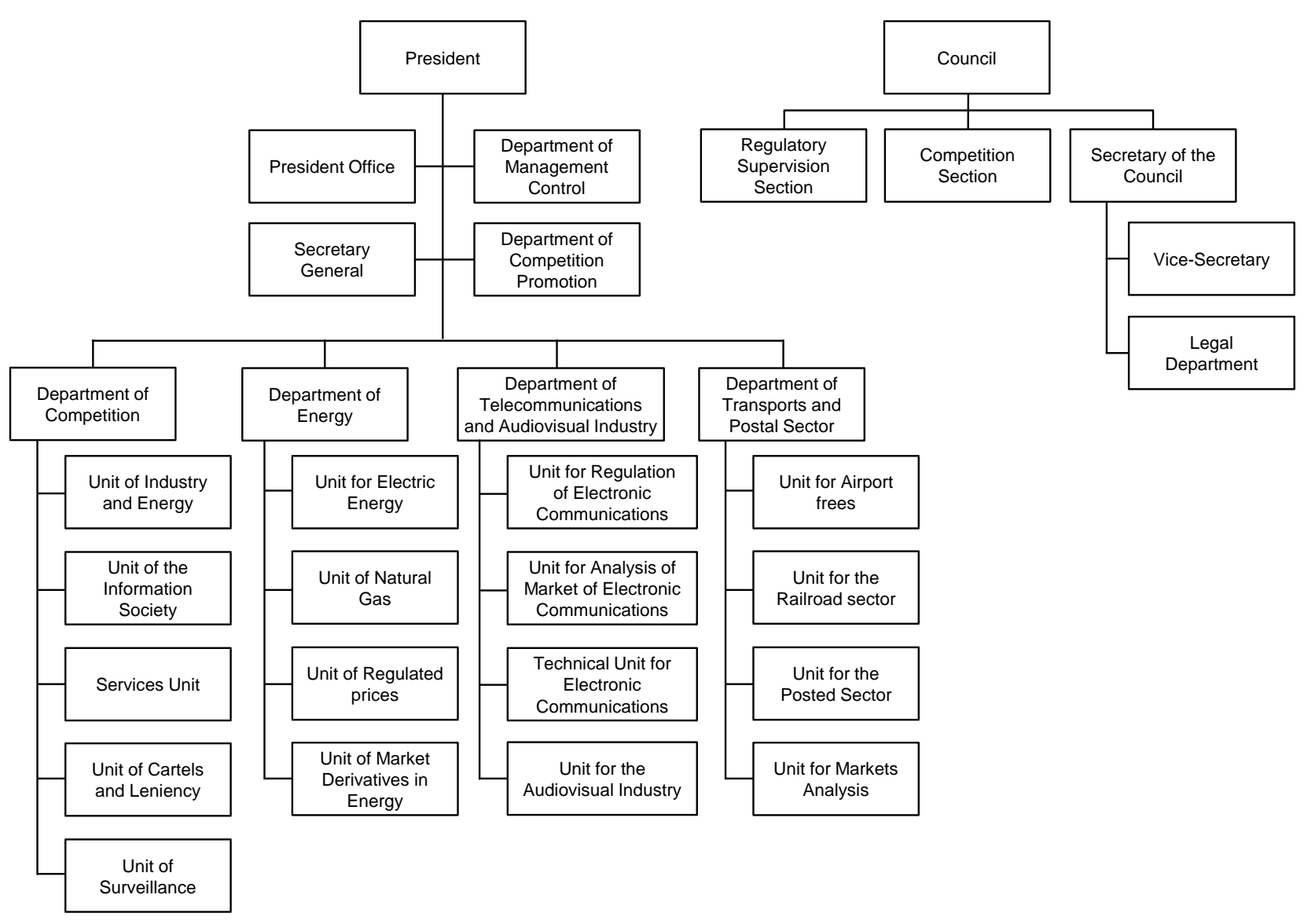

Source: CNMC

The CNMC Plenary Council appoints the director-generals who, in principle, need to be civil servants, although exceptionally non-civil servants could also be appointed to these functions (Arts. 25, 26.3 and 31.5 of Law 3/2013). The appointment will be made according to general Spanish procedures for appointing director-generals in the public administration.

\section{B. Legal Dimension}

Apart from the reform of the institutional framework, the law establishing the CNMC has also introduced changes on the legal front, devolving administrative and investigation competencies to the Spanish Ministry of Industry in two policy areas, the audiovisual and the energy sectors (see Table 4 for the details). 
Table 4

\section{Legal competences attributed to the Spanish Ministry of Industry by Law 3/2013 establishing the CNMC}

\begin{tabular}{|c|c|}
\hline $\begin{array}{l}\text { Audiovisual Sector } \\
\text { Additional disposition no. } 7 \text { in Law 3/2013 }\end{array}$ & $\begin{array}{l}\text { Energy Sector } \\
\text { Additional disposition no. } 8 \text { in Law 3/2013 }\end{array}$ \\
\hline $\begin{array}{l}\text { - To receive the kick-off activity notifications from } \\
\text { audiovisual operators. } \\
\text { - To administer the national operators registry. } \\
\text { - To decide about any matter related to the } \\
\text { audiovisual licenses and permits such as their } \\
\text { granting, cancellation, duration, etc. } \\
\text { - To verify the law concerning the limitations on } \\
\text { the acquisition of shares by operators. }\end{array}$ & $\begin{array}{l}\text { Electric Sector } \\
\text { - To oversee the correct technical well- } \\
\text { functioning and economic operation conditions } \\
\text { of the electricity production premises. } \\
\text { - To open investigations for breaching the } \\
\text { prescribed technical or economic operation } \\
\text { terms. } \\
\text { - Consumer protection. } \\
\text { - To make the clearing of the transportation and } \\
\text { distribution network costs. } \\
\text { Hydrocarbon Sector } \\
\text { - To oversee the correct technical well- } \\
\text { functioning and economic operation conditions } \\
\text { of the electricity production premises. } \\
\text { - To open investigations for breaching the } \\
\text { prescribed technical or economic operation } \\
\text { terms. } \\
\text { - To make the clearing of the transportation and } \\
\text { distribution network costs. } \\
\text { - Consumer protection. } \\
\text { - To run the system for the certification of } \\
\text { biofuels. } \\
\text { - To oversee the activity of the Office for } \\
\text { Switching of Service Providers. } \\
\text { The competences on liquid hydrocarbon fuels } \\
\text { so far attributed to the CNE. }\end{array}$ \\
\hline
\end{tabular}

Source: Law 3/2013 on the Creation of the CNMC.

Furthermore, the new law has attributed to the Ministry of Industry the powers on merger control on the energy sector that were previously held by the sector regulator, CNE. The configuration of the competition policy in the Spanish energy sector has been a controversial issue in recent times (see Federico and Vives, 2008, for a detailed account and Trillas, 2013, for a more recent comprehensive review of the regulated sectors in Spain). According to Trillas (2013) the independence of the Spanish energy regulator in particular has been challenged, in part, as a byproduct of the energy liberalization process that took place in Europe after 2000.

In particular, all big Spanish electricity firms have participated in this process, either as buyers, targets or both. On this highly sensitive issue, the Spanish government had retained for itself the last word on merger control in the energy sector until the mid-2000s. However, with the justification of seeking greater independence in the merging decisions in the electricity sector, the more substantial powers regarding merger control were later transferred to the CNE ("Function 14"). Now, the legal change introduced by the CNMC law devolves the mergercontrol power to the Spanish Ministry of Industry and, as such, it can hardly be seen as an improvement. 
In addition to this, the Spanish government, at the time the present paper is being finished, is reportedly attempting to cut back the regulation powers in the telecommunication sector, devolving back competences to the ministry. This was not done enacted in Law 3/2013 establishing the CNMC; rather it is intended to be brought about by means of a new telecommunications law, which is currently under deliberation in the senate (the lower house of parliament). According to reports issued by the former, already replaced telecommunications Spanish regulator (CMT) as well as public remarks by the new CNMC president, the Spanish telecommunication regulatory body is currently among those with the fewest number of competences across the EU (see Table 5 for a comparison with the other four largest EU economies). According to leaked news reports, the government is further reducing CNMC competences by attributing to the Ministry of Industry functions such as conflict resolution between operators (portability of mobile telephone numbers), misuse in networks, inspection, consumer protection, the relationship with regional governments, the management of the registry of operators, and the declaration of main operations, among others. Apparently, it is precisely regarding the telecommunications front that EU Commissioner Nellie Kroes sent a letter to the Spanish government warning against its anti-competition moves and threatening to impose sanctions should the independence of the new authority not be protected.

\section{Table 5}

Legal competences of the telecommunications national regulatory bodies (selected countries)

\begin{tabular}{lccccc}
\hline & $\begin{array}{c}\text { Germany } \\
\text { BNETZA }\end{array}$ & $\begin{array}{c}\text { France } \\
\text { ARCEP }\end{array}$ & $\begin{array}{c}\text { U.K. } \\
\text { OFCOM }\end{array}$ & $\begin{array}{c}\text { Italy } \\
\text { AGCOM }\end{array}$ & $\begin{array}{c}\text { Spain } \\
\text { CMNV }\end{array}$ \\
\hline Market regulation & $\mathrm{X}$ & $\mathrm{X}$ & $\mathrm{X}$ & $\mathrm{X}$ & $\mathrm{X}$ \\
Network security & & & $\mathrm{X}$ & $\mathrm{X}$ & \\
Spectrum management & $\mathrm{X}$ & $\mathrm{X}$ & $\mathrm{X}$ & $\mathrm{X}$ \\
Consumer protection & $\mathrm{X}$ & $\mathrm{X}$ & $\mathrm{X}$ & $\mathrm{X}$ \\
Other (e-commerce, etc.) & $\mathrm{X}$ & & & $\mathrm{X}$ \\
\hline
\end{tabular}

Source: National regulatory bodies.

\section{Discussion and Conclusions}

For various reasons, several EU countries are reforming their regulatory and/or competition institutional frameworks. This is the case in Spain, where the government has created in 2013 a new authority, the CNMC, which integrates the functions of the former competition authority, the CNC, together with those of seven regulatory authorities (energy, telecommunications, postal services, railway, gambling, audiovisual industries, and air transport).

The first consideration, from an international comparative perspective, is that this model of "absolute integration" adopted by the Spanish government is relatively rare in the EU, with only the Netherlands and Estonia having a comparable integrated setup. However, the rationales for integration appear to be different in the cases of Spain and the Netherlands. In Spain, the integration is chiefly justified on allegations of reaping the potential benefits of economies of scale and bringing about stronger "institutional reliability." Obviously only time will tell whether the CNMC reform meets those desirable goals. In the case of the Dutch Authority for Consumers and Markets, its entire strategic shift gravitates around consumers' welfare as its central concern. This is instrumented practically by creating a full-fledged 
consumer department and by setting up a Web service - the ConsuWije - that advises consumers on their rights. In the same vein, it is noteworthy that the recent reform of the Competition and Markets Commission in the United Kingdom has been explicitly oriented towards greater consumer protection.

By contrast, the new Spanish CNMC appears not to be active, in the same order of magnitude, in reaching out to consumers and responding to their concerns. To be fair, it should be noted that the Spanish Constitution attributes to the regional governments legal competences regarding consumers protection. Therefore, any meaningful move in the direction of more effective and direct consumer protection in Spain needs political consensus between the central government and the regional governments.

The second consideration is that, acknowledging a priori that it is very hard to establish a superior institutional model, there are some international good practices that any sound reform should be tested against. This evidence comes from both the EU and wider international experiences. To start with, the transatlantic experience suggests that well-performing competition authorities feature rigorous economic analyses in a prominent role. For instance, the Dutch authority, like many others in the EU and like the Commission's DG Competition itself, has an Office of the Chief Economist, while currently there is nothing comparable to this function in the CNMC. Secondly, the most advanced competition authorities rely on ambitious investigative tools that "have sharp teeth" and that deliver useful information in the information-gathering phase and for the preparation of documentation in the cases they handle. In this respect, the reform in the Spanish institutional framework apparently has not brought fresh investigative powers and tools to the CNMC. Thirdly, there is consensus that the accountability and assessment of the regulatory and competition authorities is of capital importance to effectively deliver business confidence and build credibility. In this respect, the CNMC has an internal audit unit that seems more directed towards establishing a proper internal management control system of the CNMC (by controlling operations and budget) than towards performing a comprehensive and regular external impact analysis of its activities.

Another issue that the CNMC reform has raised is the devolution of legal competences from the regulators (either the individual, sector-specific existing before the reform or the new CNMC itself) to the ministry. This economic and political operation has been conducted in two stages. In the first, on the occasion of the passing of Law 3/2013 establishing the CNMC some administrative and control powers have been transferred by the government from the regulators to the Ministry of Industry in the audiovisual and energy sectors. In the same law, the government has recovered control over merger operations in the electricity sector, which has been a very delicate issue in the past in Spain. In the second stage, the government is apparently to regain control of some competences in the regulation of the telecommunications sector. At the time this paper is being finished there is yet a final legal text on the new law on telecommunications, and this is based on news reports. However, regardless of how the case in the telecommunication sector finally unfolds, it clear that the process of the creation of the CNMC has been used by the government to go against international best practices and recover legal competences that, in general, should be better allocated in independent regulatory authorities.

Finally, and probably the single most important factor in assessing the functioning of the regulatory and competition system, is the actual degree of independence and accountability with which the authority works, independent of the particular institutional design. In this respect, the law establishing the CNMC is somehow ambivalent. 
The mechanism for renewing CNMC Council members (staggering renovation of the Council or Board every two years and non-renewable appointment terms of six years for the 10 Council members) is sound in that it follows international best practices and recommendations and it is comparable to those of most competition and regulatory authorities.

However, the government retains the right to appoint Council members, who in turn have absolute discretion in appointing the directors-general. At the same time, the CNMC reform has been taken as an opportunity by the government to devolve some regulatory powers in the energy sector to the ministries.

This control by the executive is somehow a relic of the past that should be progressively removed by migrating to a system in which, firstly, regulation is entrusted to the regulators only and, secondly, the CNMC Council members and directors-general are appointed by means of a truly open process based on merit and effectively open to institution outsiders. 


\section{References}

Cini, M., and L. McGowan (2009). Competition Policy in the European Union. Second Edition. (Palgrave Macmillan).

Cseres, K. (2010). "Comparing Laws in the Enforcement of EU and National Competition Laws," European Journal of Legal Studies, vol. 3, issue 1.

Comisión del Mercado de las Telecomunicaciones [Telecommunications Market Commission] (2012). Informe sobre el Anteproyecto de Ley de creación de la Comisión Nacional de los Mercados y la Competencia.

Comisión Nacional de la Competencia (2012a). Memoria de Actividades 2012-2013.

Comisión Nacional de la Competencia (2012b). Informe sobre el Anteproyecto de Ley de Creación de la Comisión Nacional de los Mercados y la Competencia.

Comisión Nacional de la Energía (2012). Informe sobre el Anteproyecto de Ley de creación de la Comisión Nacional de los Mercados y la Competencia.

Competition and Markets Authority (2014). Vision, values and strategy for the CMA.

European Commission (2009). Commission Staff Working Paper Accompanying the Report on the Functioning of Regulation 1/2003.

European Commission (2012). Assessment of the 2012 national reform programme and stability programme for Spain. SWD (2012) 310.

Federico, G., and X. Vives, with N. Fabra (2008). Competition and Regulation in the Spanish Gas and Electricity System. Reports of the Public-Private Sector Research Center no. 1.

Government of Spain (2012). National Reform Programme for Spain, 2012.

Government of Spain (2013). National Reform Programme for Spain, 2013.

International Competition Network (2013). Investigative Tools Reports.

UNCTAD (2008). Independence and accountability of competition authorities.

UNCTAD (2011). Foundations of an effective competition agency.

Trillas, F. (2013). The Institutional Architecture of Regulation and Competition: Spain's 2012 Reform. IESE Working Paper, WP-1067-E.

Vives, X. (ed. 2009). Competition Policy in the EU. Fifty Years on from the Treaty of Rome. Oxford University Press. 